\title{
The Violence of Non-Violence and Civil Disobedience: a Psychological Inference
}

\author{
Kingsley U. Omoyibo \\ and Anthony Afe. Asekhauno* \\ University of Benin \\ p.m.b.1154, Benin City, Edo state, Nigeria
}

Received 20.03.2016, received in revised form 21.05.2016, accepted 17.07.2016

By its very nature and philosophy, non-violence (and the practice or action of civil disobedience) amounts to violence. In its best, non-violence is the philosophy of using peaceful means, not force, to bring about political or social change. Civil disobedience implies the willful and deliberate violation of certain law, civil rule and political authority in resistance to some real or perceived injustice. In other words, civil disobedience is the philosophical tradition that upholds non-violence as the sole route to resisting oppression and injustice. This implies psychological retaliation. But the question is, is the very idea of civil disobedience, as the practice of non-violence, not itself violent? In consideration of this, this article indicated the nature of civil disobedience, provided a typology of violence, and therefrom argued that if violence implies violation (whether physical or psychological); that if non-violence denounces violence; and that if civil disobedience is the praxis of non-violence, then, going by its very nature, theory and practice, non-violence/civil disobedience amounts to some form of violation or violence - the supposed evil that it is meant to cure.

Keywords: Violence, non-violence, civil disobedience, psychology, inference.

DOI: 10.17516/1997-1370-2016-9-8-1746-1753.

Research area: politology.

\section{Introduction}

This article is committed to indicating that there is violence in the theory and practice of non-violence and civil disobedience. Commonly, the idea of 'violence' is equated with the use of force. Etymologically, the word, 'violence' finds roots in French, Greek, and Latin words. For example, the Latin root of the word, violence is a combination of two words - 'vis' (force) and past participle (Lotus) of the word 'fero' (to carry). The Latin word, 'violare' is itself a combination of these two words; and its present participle, 'violens' is a plausible source for the word, 'violence' - so that the word, 'violence' in its etymological origin, has the sense of 'to carry force' at or towards. To 'violate' therefore, the intention is to inflict injury or damage on an/a object or subject. 'Violence', therefore, can be physical or psychological. It is notable that the word, 'violation' is an interesting feature

(C) Siberian Federal University. All rights reserved

* Corresponding author E-mail address: kingsley.omoyibo@uniben.edu; anthony.asekhauno@uniben.edu 
of this etymology; this is because, both terms, 'violation' and 'violence', are of the same source. Remarkably, 'violence' is somehow a 'violation' of something; "force" against something implies, in one way or another, a 'violation' of it (Garver, 1970). The Longman Modern Dictionary defines 'violence' as "severe, using or showing great force" (Watson, 1978). This further implies that it is possible to violate persons, (even kill them), principles, nature, things, or objects, by either inflicting physical harm on them, or infringe on their rights or freedom. These acts are made more effective, debilitating and pervasive, with developments in art, science, technology, and even in human rationality. Although developments in science and technology have, doubtless, helped man to cope with emergent life problems, but besides providing the materials for violence, further, technology also has spread a world culture by its vast and effective communication system, manifesting in overt, covert, physical, or institutional forms.

Overt, direct or physical violence include such as assault, rape, mugging, murder, and many similar acts. They are direct, overt or physical form of violence - which is the most obvious form of violence, the one people often talk about. Though it may both be illegal and 'violating', it is a kind of 'A' causing 'B' to direct pain. Even the soldiers involved in a war are responsible for the acts of violence against "the enemy", at least in the sense that the violence would not have been done if they had refused to act. Thus, from this analysis, there could be direct-personal or direct institutional violence - to a body or property.

Covert, indirect or psychological violence is, on the whole, not reasonably easily recognized. It may be an ordinary threat of physical violence; we acknowledge that a person acting under such threat sort of loses his autonomy. Covert violence is complicated. The violating of others' autonomy, dignity, and rights, falls under this type of violence. For example, a young girl once shot herself, instead of her best-friend 'Pet-dog', having been instructed by her father to shoot the dog, as punishment for keeping un-excused late-hours with a lover. Her father admitted "having committed the murder", but no legal charges were brought on him. Readily, the girl did direct violence to herself. But the violence done to her by her father, recognizing the love for her pet-dog, is greater. That is psychological violence. Similarly, suppose a robber comes into a bank with a pistol, threatens to shoot one of the cashiers, and walks away with huge money. Even when the robber did not shoot, we do not say that the person who gave him the money stole it, but that the person acted under compulsion. And hence the responsibility falls on the robber who threatened the cashier. One threatened with 'being shot', and then does something which he certainly would otherwise never have done, is degraded by losing his autonomy as a person. Such violence is psychological and could also be physical.

There is also personal and institutional violence. Persons, as well as institutions commit violence - directly or indirectly. On the one hand, personal violence is when individuals are involved as individual, violence done on a private capacity: overt or covert. But where do we draw the line between when we act "on a private capacity" and "on institutional capacity?". Under personal violence, it is noteworthy that the individual acts on his own volition, and then has the responsibility.'

On the other hand, institutional violence is where social institutions are seen as responsible for the violence done by it members. The individual person's initiative and responsibility is subsumed as a member of a group or agency considered to be responsible for the action. Government officials, soldiers, schools corporal punishment, police are examples of agents of this kind of violence. But 
the question is further raised: 'does a group have a soul"? Can a group act except through the agent of individual men?

Overt-personal versus overt-institutional violence is implied in the foregoing. In the first place is direct-personal violence. This type is beyond mere threat, but the actual physical result of a direct violent action on another person or property, without his consent. As noted earlier on, whenever something is done to another person's body or property without his consent, not just a physical entity is attacked, but a 'person', a 'self'. It is done to him by force, willy-nilly. So the violence in this case is something that is easily recognizable as overt-personal violence. Arson, cruelty, murder, etc are examples of this kind of violence. Still, there are other examples of this kind of violence but with institutional undertone, e.g. police brutality, and school corporal punishment, "teachers rebuff".

But overt institutional violence is the direct violence committed as a member of a social institution; what a group tries to do to another group or a person or property. Again, mugging, riots, war, mob, etc. are examples. Here, moral and legal responsibility is difficult to establish in institutional violence, for defense is always "in the name of a "soulless' social entity (which cannot exist without the individual members). The post World War II Nuremberg trials brought this complexity into popularity. Thus, the object of this violence, often 'the enemy' is also not clear, 'soulless', but a group of individual members attached. Institutionalized violence is therefore ambiguous and difficult to justify. This is different from a normal criminal situation where police act against individual miscreants.

As already noted, covert violence is psychological and indirect. But it can still be personal or institutional. Covert personal violence occurs when one does the things that do result from his own freewill but pretend that it is a result of some mysterious force within, of some grand passion, or heredity; or one trying to hide one's personality behind a façade, is abnormal and thus cannot attract full responsibility. This is a condition Sartre calls "bad faith and inauthenticity" (Sartre, 1956). It is manipulating, degrading people, a kind of terrorism in one way or another, 'riots', and 'revolution'.

\section{Non-violence}

Historically, Thoreau, Gandhi, and Luther King Jnr. variously extolled the virtue of and practiced widespread civil disobedience - giving it enormous theoretical and practical authenticity. King Jnr. particularly wrote extensively in this regard. By his power of oration, rational ability, and the appeal of the subject, he won many followers. Agreeably, for King, for example, the action of civil disobedience (violating racial rules and culture, staging mass protests and matches thereby constituting public nuisance) did not only win him Nobel Laureate in the ' 60 s, but also led to the desegregation of viciously racial America. What is essential is that he and his lieutenants did violate racial laws.

Violation is violence and is antithetical to the achievement of peace and order in society; and so, violence must be eschewed. Unfortunately, over the centuries, man seems to have been irretrievably plunged in the shackles of violence. This is perhaps why many traditions profess what is theoretically called non-violence (though the idea of non-violence is a worldwide issue) for it is believed that 'water douses fire'. The efficacy of this sage ideal is expressed in Gandhi's claim that men "are helpless mortals caught in the conflagration of himsa, violence". And nonviolence alone is the antidote to violence. Nonviolence, to Gandhi, "is the putting of one's whole soul against the will of the tyrant... and working under this law of our being, it is possible for a single individual to defy the whole might of 
an unjust empire to save his honor, his religion, his soul, and lay the foundation for that empire's fall or its regeneration" (Wofford, 1970). What could be gleaned from this is that non-violence could make or mar in the quest for social change. According to the Dictionary of the Social Sciences, (2010) non-violence is "totalness, commitment to uprightness, excluding all forms of violation and force". This implies that non-violence is the philosophy that denounces violence, whether physical or psychological. It is an ethic of action, reaction and behaviour (when, where, how, and when to react to a perceived injustice) in consideration of perceived consequences. Non-violence is, therefore, to many, a preferred alternative choice of action; a technique for manipulating people and situations, testifying to the power of truth and love that is even attractive of the opponent both singly and enmasse. Thus non-violence is a moral weapon, and is derived from many traditions - these include the Gita (Estery and Hunter, 1971) and its idea of Ahimsa; the Bible and its admonition to 'turn the other cheek'; and Socrates' (Plato, 1990) philosophy of moral duty.

\section{Civil Disobedience}

From the roots of non-violence discussed above, various apostles of the doctrine have emerged - effectively interpreting it and using it as a social weapon for transforming society and moderating social policy formulation. For example, the efficacy of non-violence was demonstrated in India by the practical dimension (though this is less validly claimed about Africa) given to the Gita by Gandhi, in the United States by both David Thoreau and the Ebullient, resilient Nobel Laureate, Luther King, Jnr.

David Henry Thoreau (1817-1862) is sometime called the first American hippie. A Harvard College graduate, a naturalist, poet, surveyor, peace-maker, and a prostylist,
Thoreau died a bachelor, living behind legacies or foot prints of dynamic non-violence and civil disobedience philosophies in the context of social change and mobilization. His essay, Resistance to civil government, later called simply Civil disobedience, stipulates an appropriate position for an individual to hold in the face of opposition/ oppression to undesirable government policy. With some dexterity, Thoreau refused to support the American-Mexican war in mid $19^{\text {th }}$ century, and accordingly, refused to pay his poll tax, in protest. This earned him a night imprisonment. But while in the prison, his friend, Emerson, said to him: "why are you here?" Thoreau replied, "Why are you not here?" according to him, "All men recognize the right to revolution, that is, the right to refuse allegiance to and to resist the government when its inefficiency is great and unendurable". Further, Thoreau believes that "unjust laws exist"; and he asks: "Shall we be content to obey them, or shall we endeavor to amend them, and obey them until we have succeeded, or shall we transgress at once?" (Estery and Hunter, 1971, 63). Accordingly, Thoreau avers that resistance to unjust policy is the only just course. He posits that under a government which imprisons any unjustly, the true place for a man is prison. Thus the individual's role in restoring his power over the state is steadfast civil disobedience. Fruitfully, this attracted adherents like Gandhi.

In more philosophical and patterned approach, Mohandas K. Gandhi espoused a systematic and logical analysis of the religious tradition of Hinduism into his concept of nonviolence which he calls ahimsa. Born in 1869 and died later in 1948, Gandhi, in chapter 4 of his epic book, All men are brothers, argues that:

Non-violence is in the disposal of mankind. It is mightier than the highest weapon of destruction devised by the ingenuity of man. Just as one learns the art of killing in the 
training for violence, so one must learn the art of non-violence... (Gandhi, 1954, 1)

According to Gandhi, the first condition for the enhancement of non-violence is justice in every aspect of life, then the overcoming of fear, and the developing of love - especially for those that hate one. Gandhi traces the history of man from cannibalism to primitivism, hunting to nomadism, and from family to communityall dynamically towards "a progressive ahimsa and diminishing himsa". Metaphorically, Gandhi holds that:

man as animal is violent, but as spirit is nonviolent. The moment he awake to the spirit within, he cannot remain violent... No man could be actively non-violent and not rise against social injustice, no matter where it occurred $(1954,2)$.

Consequently, Gandhi recommends nonviolence approach as response to political, socioeconomic, and all forms of injustice in world affairs. What Gandhi means here is a kind of passive resistance to perceived or real injustice- a method of securing rights by personal suffering, which is the "reverse of resistance in arms". Thus anything repugnant to conscience should be resisted by what Gandhi calls "soul-force"disobedience and accepting the punishment for such breach, defiance or deviance-as against body-force which is violent. Thus go Gandhi, non-violence is "self-sacrifice". In other words, Ahimsa is, to Gandhi, not just utilitarian but "the greatest good of all which the believer can possibly die for". Non-violence is beyond the appeal of reason because that is more to the head; but the penetration of the heart "comes from suffering"not the sword. Therefore "ahimsa is the largest love", "greatest charity"; and it implies truth and fearlessness. Though it can be adequately held that man, consciously or unconsciously, commits violence, (in his eating, his working, and his social activity) such tendency could be minimized by self restraint and compassion; for "the good of violence is temporary, but it's evil permanent". Hence the strength to kill, to Gandhi, is not effective selfdefense as is the strength to die for truth.

Consequently, Gandhi recommends ahimsa because he believes in it as the true path to liberation, and historically, it had worked for Christ, Socrates, Daniel, and others at various times. However, Gandhi only prefers violence to cowardice. In a radical way, Gandhi's nonviolent activity was effective and helped in independence for India in 1947. As Maidu Nme (Estery \& Hunter, 1971, 95) noted during the 24mile "salt match" in the 1940s to several thousand non-violent resisters to British rule in India, "Gandhi's body is in jail but his soul with you... you must not even raise a hand to ward off blows" (Estery \& Hunter, 95). Only recently in the United States, Martin Luther King Jnr. popularized the idea of non-violence and made it a contemporary relevance. All his writings, (including Strength to love, The trumpet of conscience, Why we can't wait, and Where do we go from here: Chaos or community) attest to King's commitment to the theory, practice and love for active non-violence. Born in 1927 in the racial eclipsed United States, King deliberately adopted Gandhi's idea of 'Satyagraha' to the civil rights movement in USA-organized several ad hoc marches and protests in active resistance to racialism and suit for equality of all men, irrespective of race, colour, or social standing. His was simply a practical soul force based on six principles copiously embedded in his "I have a dream" speech delivered in 1963-the speech considered by many as one of the best in recent human history. Philosophically, King believes that "injustice anywhere is a threat to justice everywhere". In "any factual non-violent 
campaign", he continues, there are four basic steps.

1. Collection of facts to determine whether injustices are alive;

2. Negotiation;

3. Self-purification; and

4. Direct action (sit-ins, marches, protests, and other forms of civil disobedience).

Accordingly, there must be the existence of perceived injustice, and deliberate/direct steps must be taken to get them redressed by negotiation. We only degenerate to steps 3 and 4 when step two fails. More so, King also argues that there are two forms of laws; just laws, and unjust laws. One therefore has the moral responsibility to obey just laws, on the other hand, and disobey unjust laws, on the other. But King here differs from Thoreau and Gandhi in that he gave some indices for distinguishing just from unjust laws. He says:

a just law is man-made code that squares with the moral law or the law of God; an unjust law is a code that is out of harmony with the moral law...Any law that uplifts human personality is just. Any law that degrades human personality is unjust (King, 1968, 74-75).

It is noteworthy that in his interpretation of just and unjust laws, King's disparate with the Augustinian interpretation of same. What however strikes is that unjust law, according to King, is often one inflicted by a majority on a minority but which do not bind itself-the majority.

Admittedly, King's conception of and conviction for non-violence is rooted or inspired by the defiance and disobedience by the Biblical story of Shadrach, Meshach, and Abednego, on the one hand, Christ's sermons and Paul's interpretation of same, on the other. So King admonishes that though adherents to non-violence could be branded extremists, as was Jesus, Amos,
Paul, and even Lincoln, it is better to be so branded for the sake of love, truth, goodness, and justice to obtain. Thus commitment to non-violence should be done with some "discrete, discipline, and integrity amidst creative suffering".

\section{Analysis and Conclusion}

The ultimate goal of any philosophy is the welfare of the upliftment of human welfare and dignity through the powers of solely human understanding regardless of whatever social antecedents, thus the idea of non-violence and civil disobedience as potent weapons of social change, which has long been accepted so, prompts some thinking. Implicit in this discourse, two facts emerge from the foregoing. In the first place, soul force could be very debilitating and deleterious. Soul force, in the process of winning could even destroy its object or target-who could be distressed, depressed, sorrowful, and remorseful, leading to some psychological misbalance. All these have grievous health consequences. In this way, psychological violence could have violent physical manifestations. Again, sit-ins deny the performance of duty and no production for human good; matches constitute public nuisance-especially to persons who may not be the primary source of the grievance; and worse is the case of demonstrations, for, by the fact of the contagious nature of human emotions, it could easily degenerate to physical violence (injuries, stealing, rape, et cetera).

More so, from our analyses of the relationship between non-violence and civil disobedience, it is clear that disobedience is disobedience of something-which means violating such thing. Such inference could be very handy. Since inference is the process of moving from the acceptance of some propositions, to the acceptance of others (Blackbum, 1996, 193) it is possible to construct somewhat syllogistic forms, as in: 
All violence imply violation or force

All violation or force is wrong

Therefore, all violence is wrong.

Obviously, the extrapolation from the fact that anything that qualifies as a violation is wrong is easy. Invariably, nothing violates that is not wrong. In this way, also obviously, no violating action can be good-no matter its end. Consequently, personal and institutional violence is wrong. Hence, by instantiation, this claim could be exposed by the Modus Ponens variant of form 'A' above:

B.

All violation or force is violence

Non-violence/Civil disobedience implies violation or force

Therefore non-violence/Civil disobedience is violence.
Notably, the only possible way of falsifying the above syllogistic structure is to first indicate that non-violence/civil disobedience is not violation, in which case it, as a weapon, could not have been adopted in the first place or it is effective and misconceived. This accounts for the apparent validity of the form:

C.

All violation or force is wrong

Non-violence/Civil disobedience is violation

Therefore, Non-violence/Civil disobedience is wrong.

From all three instances, we can but conclude, following the typology of violence indicated in our study, that the idea of non-violence and civil disobedience irretrievably amounts to violence-a consequence, which doubtless cannot diminish the employment and potency of civil disobedience as a potent weapon of social change.

\section{References}

Blackbum, S.B. (1996). Oxford dictionary of philosophy. New York: Oxford University Press.

Estery, G. and Hunter, D. (1971). Non-violence. Toronto: Ginn and Company.

Gandhi, M.K. (1954). All men are brothers. New York: Mentor New American Library.

Gandhi, M.K. All men are brothers. Quoted In: Estery, G. \& B. Hunter, Non-violence, Toronto: Ginn and Company, 1971.

Garver, N. (1970). What is violence. In: Bierman, A.K. and J. Gold, (ed.) Philosophy for a new generation. New York: The Macmillan Company, 1970, 180.

King, M.L. Jnr. (1968). The trumpet of conscience. New York: Harper and Row.

Plato, (1990). Crito. In: Bernet, S. and Bedau, H., (eds.) Current issues and enduring questions Boston: St. Martin's Press, 1990, 433-446

Sartre, J.P. (1956). Being and nothingness. In: Stumpf, E.S. and Fieser, J. (eds.) Socrates to Sartre: A history of philosophy, New York: McGraw-Hill, 2003, 466.

The dictionary of the social sciences. Wikipedia, The free encyclopedia. Accessed: $22^{\text {nd }}$ October, 2010.

The holy Bible

Thoreau, H.D. (1849). Civil disobedience. In: Estery, G. \& B Hunter, Non-violence, Toronto: Ginn and Company, 1971.

Watson, O. (1978). Longman modern English dictionary.

Wofford, H. Jnr. (1970). Non-violence and the law: The law needs help. In: Bierman, A.K. \& Gold, J. Philosophy for a new generation. New York: The Macmillan Company, 1970, 367-375. 


\title{
Насильственная природа ненасилия
}

\section{и гражданского неповиновения:}

психологические аспекты

\author{
К.Ю. Омоибо, Э.Афэ. Асехауно \\ Бенинский университет \\ Бенин, итат Эдо, Нигерия
}

\begin{abstract}
По самой своей природе и философии ненасилие (как и практика гражданского неповиновения) сводится к насилию. В лучшем случае ненасилие является философией использования мирных средств, а не силы, целью которой являются политические или социальные изменения. Под гражданским неповиновением понимается умылиленное и преднамеренное нарушение определенного закона, гражданского права и политической власти как ответ на какую-либо реальную или кажущуюся несправедливость. Иными словами, гражданское неповиновение является философской традицией, которая поддерживает ненасилие в качестве единственного пути против угнетения и несправедливости. Это предполагает ответный психологический удар. Вопрос заключается в том, является ли сама идея гражданского неповиновения как практика ненасилия насильственной сама по себе? С учетом этого в данной статье рассматривается природа гражданского неповиновения, типология насилия. Исходя из этого утверждается, что если насилие означает нарушение (будь то физическое или психологическое), если ненасилие денонсирует насилие и что если гражданское неповиновение является практикой ненасилия, то по своей природе теория и практика применения ненасилие/гражданское неповиновение представляет собой нарушение или насилие в той или иной форме - то самое зло, которое оно призвано искоренить.
\end{abstract}

Ключевые слова: насилие, ненасилие, гражданское неповиновение, психология, предположение.

Научная специальность: 23.00.00 - политология. 